\title{
Cross talk between cAMP and p38 MAPK pathways in the induction of leptin by hCG in human placental syncytiotrophoblasts
}

\author{
Y C Ge, J N Li ${ }^{1}$, X T Ni, C M Guo ${ }^{1}$, W S Wang ${ }^{1}, \mathrm{~T}_{\text {Duan }}$ and K Sun ${ }^{1}$ \\ Shanghai First Maternity and Infant Health Hospital, Tongji University, Shanghai 200040, People's Republic of China \\ and ${ }^{7}$ School of Life Sciences, Fudan University, 220 Handan Road, Shanghai 200433, People's Republic of China
}

Correspondence should be addressed to K Sun; Email: sungang@fudan.edu.cn

T Duan; Email: tduan@yahoo.com

\begin{abstract}
Leptin produced by the placental syncytiotrophoblasts participates in a number of processes in pregnancy including implantation, proliferation of the cytotrophoblasts, and nutrient transfer across the placenta. Despite the functional significance of leptin in pregnancy, the regulation of leptin synthesis is poorly understood in human placental syncytiotrophoblasts. In this study, we investigated the role of endogenous human chorionic gonadotropin (hCG) in the regulation of leptin production as well as the underlying mechanism involving the cross talk between cAMP and p38 mitogen-activated protein kinase (MAPK) pathways. We found that neutralization of endogenous hCG with its antibody dose dependently decreased leptin mRNA level and secretion, whereas exogenous hCG increased leptin mRNA level and secretion. Activation of the cAMP pathway with dibutyryl cAMP (db cAMP) or forskolin recapitulated the stimulatory effect of hCG on leptin expression. Inhibition of protein kinase A with $\mathrm{H} 89$ not only reduced the basal leptin expression but also attenuated the induced leptin expression by hCG. Treatment of the syncytiotrophoblasts with db cAMP and hCG phosphorylated p38 MAPK. Inhibition of p38 MAPK with SB203580 not only reduced the basal leptin production but also attenuated the leptin-induced production by both hCG and db cAMP. These data suggest that endogenous hCG plays a significant role in maintaining leptin production in human placental syncytiotrophoblasts, and this effect involves a cross talk between cAMP and p38 MAPK pathways.

Reproduction (2011) 142 369-375
\end{abstract}

\section{Introduction}

Leptin is crucial in the regulation of food intake and energy expenditure (Margetic et al. 2002). Although adipocytes are regarded as the primary source for leptin in human body, the placental syncytiotrophoblasts provide an additional source during pregnancy (Masuzaki et al. 1997). The production of leptin from placental syncytiotrophoblasts increases with gestational age, leading to an increased leptin level in maternal circulation (Masuzaki et al. 1997, Highman et al. 1998, Lage et al. 1999). In pathological conditions of pregnancy such as preeclampsia, gestational diabetes, and intrauterine growth retardation, the level of leptin in maternal circulation is further increased (Hytinantti et al. 2000a, b, Jansson et al. 2003). Leptin produced by the placental syncytiotrophoblasts has been reported to be implicated in the regulation of implantation of the fertilized ovum, proliferation of the cytotrophoblasts, and nutrient transfer across the placenta to the fetus in a paracrine or intracrine manner via leptin receptor present in the intrauterine tissues (Henson et al. 1998, Jansson et al. 2003, Henson \& Castracane 2006, Forhead
\& Fowden 2009). Despite the functional significance of leptin in pregnancy, the regulation of leptin synthesis is poorly understood in human placental syncytiotrophoblasts. It is demonstrated that the transcription of leptin gene in human placenta uses a placenta-selective element in the enhancer (Bi et al. 1997, Ebihara et al. 1997). Activation of the cAMP pathway leads to an increase of leptin synthesis in human placental trophoblasts (Coya et al. 2001, Maymo et al. 2010), which is in obvious contrast to the decreased leptin production upon activation of the cAMP pathway in adipocytes (Gettys et al. 1996, Szkudelski et al. 2005). It is reported that this induction of leptin upon activation of the CAMP pathway involves a cross talk to the extracellular signalregulated kinase (ERK1/2) in human placental cells (Maymo et al. 2010). During pregnancy, placental syncytiotrophoblasts synthesize a large amount of human chorionic gonadotropin (hCG). The role of hCG in the maintenance of pregnancy is well known for stimulating progesterone synthesis, promoting uterine quiescence, regulating implantation, and controlling trophoblastic hormonal secretion and differentiation 
(Shi et al. 1993, Cronier et al. 1994, Kraiem et al. 1994, Kurtzman et al. 2001). It is well established that hCG shares the same receptor with pituitary LH and the $\mathrm{hCG} / \mathrm{LH}$ receptor is coupled to Gas protein using the cAMP pathway in its signal transduction (Strauss et al. 1992). Exogenous hCG is reported to stimulate leptin production in human placental explants and immortalized cell lines (Maymo et al. 2009). However, it is not known whether the endogenous hCG plays any role in the maintenance of leptin production in human placental syncytiotrophoblasts. In addition to ERK, there are other members in the mitogen-activated protein kinase (MAPK) family, including p38 MAPK and SAPK/ JNK (Roux \& Blenis 2004). As activation of both p38 MAPK and ERK1/2 has been reported to be associated with placental trophoblast differentiation (Daoud et al. 2005), and activation of p38 MAPK is known to increase leptin synthesis in adipocytes (Trujillo et al. 2006), we postulated that activation of p38 MAPK may also be involved in hCG/cAMP-induced leptin production in human placental syncytiotrophoblasts. In this study, we addressed the above issues in cultured primary human placental syncytiotrophoblasts.

\section{Results \\ Effect of exogenous and endogenous hCG on leptin production in human placental syncytiotrophoblasts}

Our previous study has shown that the placental trophoblasts achieved extensive syncytialization 3 days after plating in medium containing 10\% newborn calf serum (NCS; Ni et al. 2009). The viability and syncytialization of the cells were not affected by the treatments in serum-free medium thereafter. Measurement with quantitative real-time PCR (qRT-PCR) revealed that treatment of the syncytiotrophoblasts with exogenous hCG increased leptin mRNA levels in a concentration-dependent manner with the maximal effect observed around $10 \mathrm{lU} / \mathrm{ml}$ (Fig. 1A). hCG at $10 \mathrm{IU} / \mathrm{ml}$ significantly increased both leptin mRNA level and secretion (Fig. 1B and C). Neutralization of endogenous hCG with its antibody decreased leptin mRNA level in a dose-dependent manner (0, 1:250, $1: 125,1: 62.5$; Fig. 2A). The leptin level in the culture medium was also significantly decreased by hCG antibody (1:62.5; Fig. 2B). These results suggest that both exogenous and endogenous hCG play a significant role in upregulating leptin expression and secretion in human placental syncytiotrophoblasts.

\section{Role of the CAMP pathway in the upregulation of leptin production by hCG in human placental syncytiotrophoblasts}

$\mathrm{HCG} / \mathrm{LH}$ receptor is coupled to the cAMP signal transduction. Our previous study also demonstrated
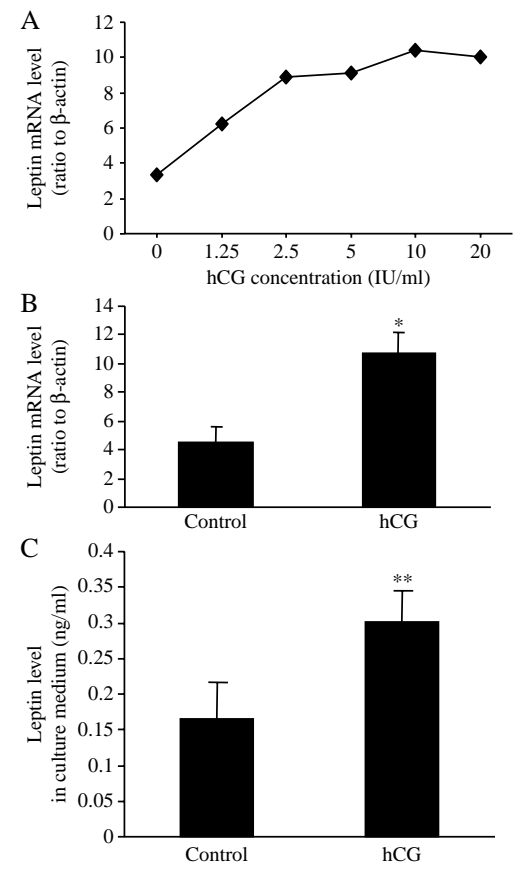

Figure 1 Effect of exogenous hCG on the production of leptin in human placental syncytiotrophoblasts. (A) Exogenous hCG increased leptin mRNA level in a concentration-dependent manner. (B) Exogenous hCG $(10 \mathrm{IU} / \mathrm{ml})$ significantly increased leptin mRNA level. ${ }^{*} P<0.05$ versus control, $n=8$. (C) Exogenous hCG $(10 \mathrm{IU} / \mathrm{ml})$ significantly increased leptin level in the culture medium. ${ }^{* *} P<0.01$ versus control, $n=4$.

that neutralization of endogenous hCG decreased the cAMP level in the syncytiotrophoblasts ( $\mathrm{Ni}$ et al. 2009). Thus the effect of activation or inhibition of the cAMP pathway on the induction of leptin production by hCG was investigated in the syncytiotrophoblasts. Activation of the adenylyl cyclase with forskolin $(100 \mu \mathrm{M})$ or mimicking the effect of cAMP with dibutyryl cAMP (db cAMP; $100 \mu \mathrm{M})$ significantly increased leptin mRNA level (Fig. 3A and B). Inhibition of protein kinase A (PKA) with H89 $(10 \mu \mathrm{M})$ not only decreased the basal leptin mRNA level but also attenuated the stimulation of leptin mRNA expression by hCG $(10 \mathrm{lU} / \mathrm{ml}$; Fig. 3C). The dramatic reduction of leptin expression by $\mathrm{H} 89$ alone may derive from the inhibition of the basal leptin expression maintained by endogenous hCG. These data suggest that the cAMP pathway plays a significant role in the upregulation of leptin expression by hCG in human placental syncytiotrophoblasts.

\section{Role of p38 MAPK in the induction of leptin production by hCG/cAMP in human placental syncytiotrophoblasts}

Treatment of the syncytiotrophoblasts with $\mathrm{db}$ cAMP $(100 \mu \mathrm{M})$ or hCG $(10 \mathrm{IU} / \mathrm{ml} ; 0,15,30$, and $60 \mathrm{~min})$ induced the phosphorylation of p38 MAPK in a timedependent manner with the maximal effect observed at 30 min (Fig. 4). SB203580 (10 $\mu$ M), an inhibitor of p38 MAPK, not only decreased the basal leptin mRNA level 


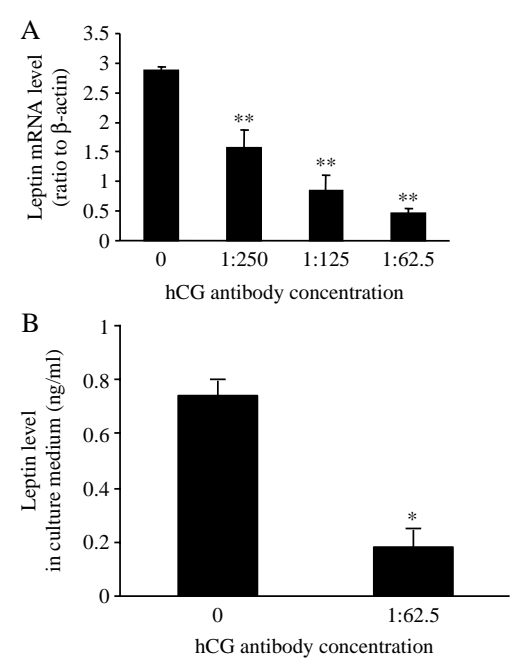

Figure 2 Effect of hCG antibody on the production of leptin in human placental syncytiotrophoblasts. (A) hCG antibody decreased leptin mRNA level in a dose-dependent manner. ${ }^{*} P<0.05,{ }^{* *} P<0.01$ versus normal serum control (0), $n=3$. (B) hCG antibody decreased leptin level in the culture medium. ${ }^{*} P<0.05$ versus normal serum control (0), $n=3$.

and secretion but also attenuated the induction of leptin mRNA expression and secretion by either hCG (10 IU/ $\mathrm{ml}$; Fig. 5A and B) or db cAMP $(100 \mu \mathrm{M})$ significantly (Fig. 6A and $\mathrm{B}$ ), suggesting that the induction of leptin mRNA expression and secretion by hCG/cAMP is, at least in part, mediated via p38 MAPK in human placental syncytiotrophoblasts.

\section{Discussion}

By using cultured primary human placental syncytiotrophoblasts, we demonstrated that endogenous hCG played a significant role in maintaining leptin expression and secretion, and a cross talk between the cAMP and the p38 MAPK pathways was involved in this process.

Although there is little doubt about the functional significance of leptin in pregnancy, it is less clear how leptin expression and secretion are regulated in the placenta. Studies have shown that proinflammatory cytokines, estrogen, glucocorticoids, and activation of the cAMP pathway are all inducers of leptin synthesis in placental syncytiotrophoblasts (Chardonnens et al. 1999, Coya et al. 2001, Nuamah et al. 2004, Marinoni et al. 2008, 2010, Gambino et al. 2010). Recently it was demonstrated that exogenous hCG stimulated leptin expression in human placental cell line as well as in human placental explants (Maymo et al. 2009), which is confirmed by the findings in this study that exogenous hCG or activation of cAMP pathway with forskolin and $\mathrm{db}$ cAMP induced leptin production in primary placental syncytiotrophoblasts. Studies have shown that activation of cAMP pathway inhibited exogenous hCG-induced leptin production despite that both hCG and activation of
CAMP pathway were found to induce leptin production (Maymo et al. 2009, 2010). This apparent contradiction may not reflect the physiological situation as the placental syncytiotrophoblasts produce abundant endogenous hCG, and the combination of exogenous hCG and other inducers of cAMP pathway activation might result in non-physiological outcome. HCG is one of the most abundant hormones secreted by the placental syncytiotrophoblasts in pregnancy, which may influence syncytiotrophoblasts in a paracrine or an autocrine manner (Kurtzman et al. 2001). Thus the cAMP pathway may have already been activated by endogenous hCG via the Gas-protein coupled-hCG/LH receptor at the basal state (Bahl 1977). This notion is supported by the findings that both hCG antibody and PKA inhibitor H89 could significantly decrease leptin expression and secretion. HCG has important implications in the maintenance of pregnancy (Shi et al. 1993, Kurtzman et al. 2001). Leptin is also reported to be involved in implantation, proliferation of the cytotrophoblasts, and nutrient transfer across the placenta (Jansson et al. 2003, Henson \& Castracane 2006, Magarinos et al. 2007, Forhead \& Fowden 2009). The induction of leptin production by hCG in the syncytiotrophoblasts may thus contribute to the maintaining effect of hCG on pregnancy.

As placental leptin is mainly synthesized by the syncytiotrophoblasts, the process of syncytium formation

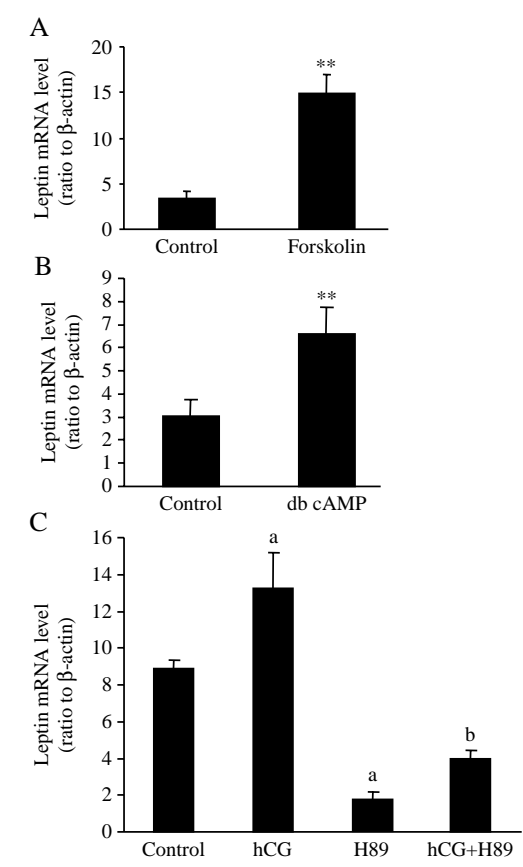

Figure 3 Effect of cAMP pathway on leptin mRNA expression in human placental syncytiotrophoblasts. (A) Activation of adenylyl cyclase with forskolin $(100 \mu \mathrm{M})$ increased leptin mRNA level. ${ }^{*} P<0.01, n=5$.

(B) Dibutyryl cAMP (db cAMP, $100 \mu \mathrm{M})$ increased leptin mRNA level, $n=3$. ${ }^{* *} P<0.01$. (C) H89 (PKA inhibitor, $10 \mu \mathrm{M}$ ) attenuated both basal and hCG $(10 \mathrm{lU} / \mathrm{ml})$-induced leptin mRNA expression. ${ }^{\mathrm{a}} P<0.05$ versus control, ${ }^{\mathrm{b}} P<0.01$ versus $\mathrm{hCG}, n=3$. 

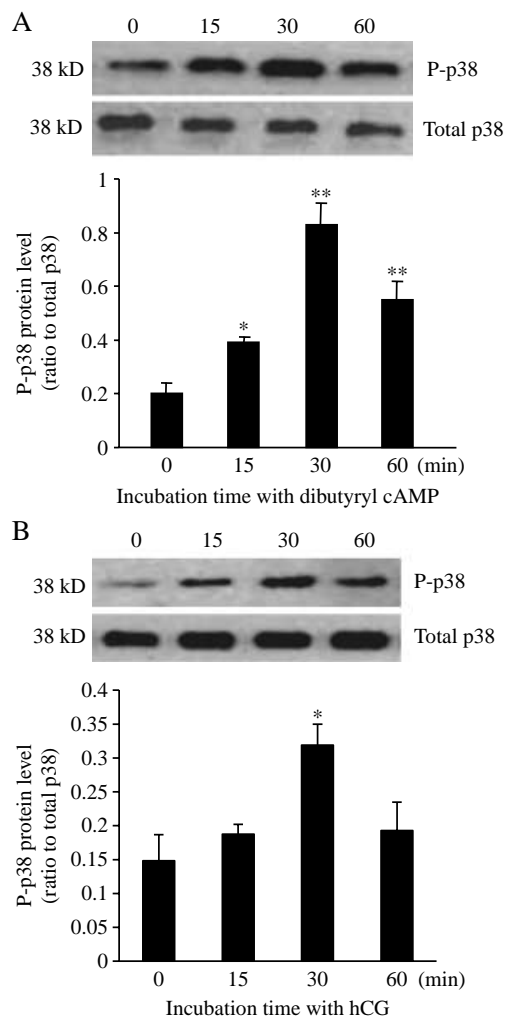

Figure 4 Phosphorylation of p38 MAPK (P-p38) induced by dibutyryl cAMP $(100 \mu \mathrm{M})(\mathrm{A})$ and hCG $(10 \mathrm{IU} / \mathrm{ml})(\mathrm{B})$ in human placental syncytiotrophoblasts. Upper panels of $A$ and $B$ are the representative blots. Bottom panels are the average data of three experiments. ${ }^{*} P<0.05,{ }^{* *} P<0.01$ vs 0 min.

may promote the production of leptin (Masuzaki et al. 1997, Ashworth et al. 2000). In addition, both hCG and cAMP pathway have been demonstrated to promote trophoblast syncytialization (Strauss et al. 1992, Shi et al. 1993, Yang et al. 2003), which may, at least in part, account for the effect of hCG/cAMP on leptin production during syncytialization. However, in this study, the effect of $\mathrm{hCG} / \mathrm{cAMP}$ on leptin production was studied in the placental trophoblasts 3 days after plating in medium containing $10 \%$ NCS. Under this incubation condition, maximal syncytialization is known to have taken place (Kliman et al. 1986, Ni et al. 2009). Therefore we believe that hCG/cAMP may also increase leptin production via induction of its mRNA expression in syncytiotrophoblasts, which is supported by the findings that hCG/ cAMP is capable of stimulating leptin promoter activity (Maymo et al. 2009, 2010).

Cross talk between cAMP and MAPK pathways has been documented at multiple levels in a number of cell types (Bhat et al. 2007, Rey et al. 2007, Sengupta et al. 2007). It was demonstrated that the induction of leptin expression by the CAMP pathway was mediated via the activation of ERK/MAPK in a placental cell line (Maymo et al. 2010). Furthermore it was found that activation of p38 MAPK by forskolin could be inhibited by $\mathrm{H} 89$ in osteoblastic cells (Rey et al. 2007). Moreover induction of CREB phosphorylation by forskolin was found to be mediated through activation of p38 MAPK in oligodendrocytes (Bhat et al. 2007). Of interest, it was reported that hCG induced neuronal differentiation through activation of both ERK and p38 MAPK via hCG receptor activation of cAMP pathway (Meng et al. 2007). As activation of p38 MAPK is known to increase leptin synthesis in adipocytes (Trujillo et al. 2006), we postulated that cross talk between CAMP and p38 MAPK pathway is possibly involved in the induction of leptin production by hCG in placental syncytiotrophoblasts. This notion is supported by our findings that both basal and leptin-induced production by either hCG or $\mathrm{db}$ cAMP could be attenuated by p38 MAPK inhibitor as well as by the observation that the phosphorylation of $\mathrm{p} 38$ MAPK was significantly increased by $\mathrm{db}$ cAMP and hCG in the syncytiotrophoblasts.

In summary, we presented evidence in this study that endogenous hCG maintains leptin production via activation of the CAMP pathway. Subsequent phosphorylation of p38 MAPK following activation of cAMP pathway may account, at least in part, for the increased leptin production by hCG in cultured human placental syncytiotrophoblasts.

\section{Materials and Methods}

\section{Human placental trophoblast cell culture}

Human placentae were obtained from uncomplicated normalterm (38-40 weeks) pregnancies after elective cesarean section

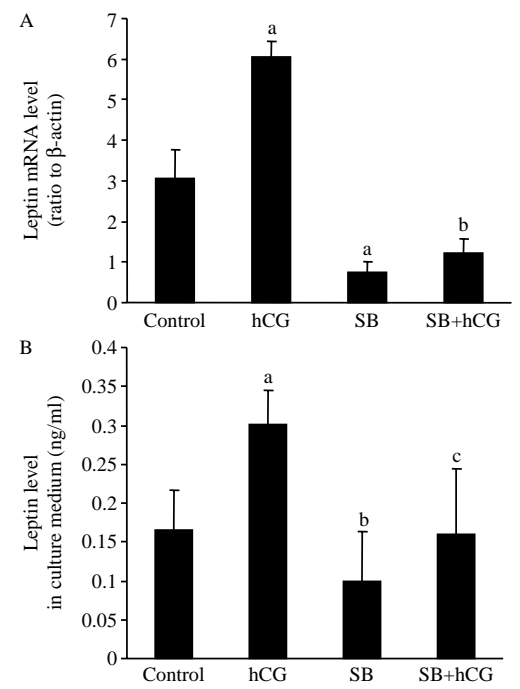

Figure 5 (A) Effect of SB203580 (p38 MAPK inhibitor, $10 \mu \mathrm{M}$ ) on the basal and hCG $(10 \mathrm{IU} / \mathrm{ml})$-induced leptin mRNA expression in human placental syncytiotrophoblasts. ${ }^{\mathrm{a}} P<0.01$ versus control, ${ }^{\mathrm{b}} \mathrm{P}<0.01$ versus hCG, $n=3$. (B) Effect of SB203580 (p38 MAPK inhibitor, $10 \mu \mathrm{M}$ ) on the basal and hCG $(10 \mathrm{lU} / \mathrm{ml})$-induced leptin secretion in human placental syncytiotrophoblasts. ${ }^{\mathrm{a}} P<0.05,{ }^{\mathrm{b}} P<0.01$ versus control, ${ }^{\mathrm{c}} P<0.01$ versus $\mathrm{hCG}, n=4$. 

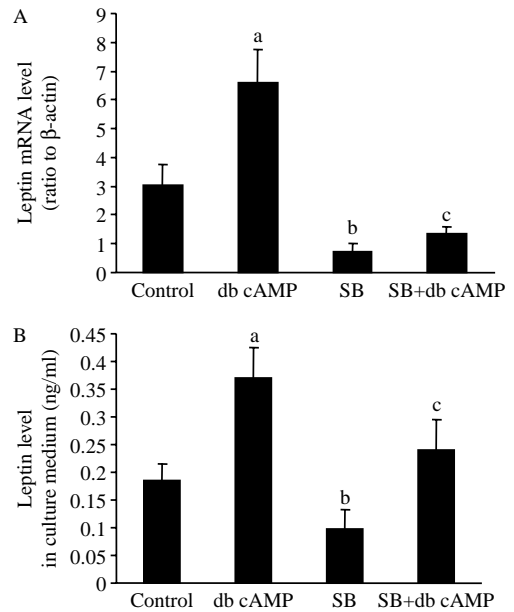

Figure 6 (A) Effect of SB203580 (p38 MAPK inhibitor, $10 \mu \mathrm{M}$ ) on the basal and dibutyryl cAMP (db cAMP, $100 \mu \mathrm{M}$ )-induced leptin mRNA expression in human placental syncytiotrophoblasts. ${ }^{\mathrm{a}} P<0.01$, ${ }^{\mathrm{b}} P<0.05$ versus control, ${ }^{\mathrm{c}} P<0.01$ versus $\mathrm{db}$ cAMP, $n=3$. (B) Effect of SB203580 (p38 MAPK inhibitor, $10 \mu \mathrm{M}$ ) on the basal and dibutyryl cAMP (db cAMP, $100 \mu \mathrm{M}$ )-induced leptin secretion in human placental syncytiotrophoblasts. ${ }^{\mathrm{a}} P<0.01,{ }^{\mathrm{b}} P<0.05$ versus control, ${ }^{\mathrm{c}} P<0.01$ versus $\mathrm{db}$ cAMP, $n=5$.

without labor following a protocol approved by the Ethics Committee of School of Life Sciences of Fudan University. Subjects gave informed, written consent. Placental cytotrophoblast cells were prepared using a modified method of Kliman (Kliman et al. 1986) as described previously (Sun et al. 1997). In brief, tissue aliquots were randomly removed from the maternal side of the placenta and digested with $0.125 \%$ trypsin (Sigma Chemical Co.) in DMEM (Gibco). The placental cytotrophoblasts were purified using a $5-75 \%$ Percoll (Sigma) gradient at step increments of $5 \%$. The cytotrophoblasts were plated at a density of $1.5 \times 10^{6}$ cells/well in 6-well plates for culture at $37{ }^{\circ} \mathrm{C}$ in $5 \% \mathrm{CO}_{2}, 95 \%$ air in DMEM containing $10 \%$ NCS (Gibco) to allow syncytialization in vitro for 3 days. The culture medium was replaced with serum-free medium 3 days after plating and the cells were treated with forskolin (an adenylyl cyclase stimulator, Sigma), db cAMP, an analog of cAMP (Sigma), hCG antibody (C8543, Sigma) or normal serum, hCG (Sigma) in the presence and absence of PKA inhibitor H89 (Sigma) or p38 MAPK inhibitor SB203580 (Sigma), and db CAMP in the presence and absence of SB203580. The concentrations of these reagents are shown in the Results section and in the corresponding figure legends and were chosen according to the literature report as well as our pilot study. The culture medium was collected for leptin measurement with enzyme immunoassay (EIA) $24 \mathrm{~h}$ after treatment and cells were lysed for total RNA extraction and leptin mRNA measurement with qRT-PCR. To measure the phosphorylation of p38 MAPK on activation of CAMP pathway, the syncytiotrophoblasts, after washing, were incubated in serum-free medium with db cAMP or hCG for $0,15,30$, and $60 \mathrm{~min}$, total cellular protein was then extracted for the analysis of phosphorylated, and total p38 MAPK levels with western blotting.

\section{Extraction of RNA and measurement of leptin mRNA level with qRT-PCR}

Total RNA was extracted from the placental syncytiotrophoblasts $24 \mathrm{~h}$ after treatment using UNIQ-10 RNA extraction kit (Sangon Biotech, Shanghai, China). After determination of RNA concentration, mRNA was reverse transcribed to cDNA with oligo (dT) 12-18 primer using Moloney murine leukemia virus reverse transcriptase (Promega), and cDNA was used for subsequent measurement of leptin level with qRT-PCR using power SYBR green PCR master mix (Toyobo, Osaka, Japan). Primers for amplifying leptin were $5^{\prime}$ - GATGACACCAAAACCCTCATC- 3' (sense) and 5'- GGCCACCACCTCTGTGGAGTA- $3^{\prime}$ (antisense). The annealing temperature was set at $61^{\circ} \mathrm{C}$. The absolute mRNA levels in each sample were calculated according to a standard curve set up using serial dilutions of known amounts of specific PCR product templates against corresponding cycle threshold values. To control for sampling errors, qRT-PCR for the housekeeping gene $\beta$-actin was routinely performed on each sample. Primers for amplifying $\beta$-actin were $5^{\prime}$-GGGAAATCGTGCGTGACATTAAG-3' (sense) and 5'-TGTGTTGGCGTACAGGTCTTTG-3' (antisense). The ratio of the copy number of target gene over the copy number of $\beta$-actin in each sample was obtained to normalize the expression of the target gene.

\section{Extraction of protein and measurement of p38 MAPK level with western blotting}

Total cellular protein was extracted from human placental syncytiotrophoblasts $0,15,30$, and $60 \mathrm{~min}$ after stimulation with $\mathrm{db}$ cAMP or hCG using an extraction kit from Active Motif (Carlsbad, CA, USA). Phosphatase inhibitor was included in all the buffers used in protein extraction. The levels of phosphorylated p38 MAPK and total p38 MAPK were measured following a standard western blotting protocol. Briefly, after determination of protein concentration with Bradford assay, $50 \mu \mathrm{g}$ sample protein was electrophoresed in $10 \%$ SDS-polyacrylamide gel and transferred to the nitrocellulose blot. After blocking with 5\% nonfat milk buffer, the blot was incubated with 1:500 dilution of antibodies recognizing phosphorylated p38 MAPK (Santa Cruz Biotechnology, Santa Cruz, CA, USA) and total p38 MAPK (Santa Cruz) overnight. After washing, the blot was incubated with appropriate secondary antibody conjugated with HRP (Santa Cruz) for $1 \mathrm{~h}$. The enhanced chemiluminescent detection system (Amersham) was used to detect the bands with peroxidase activity. The level of phosphorylated p38 MAPK is expressed as the ratio of band densities of phosphorylated p38 MAPK over total p38 MAPK.

\section{EIA for leptin}

Serum-free medium removed from the placental syncytiotrophoblasts $24 \mathrm{~h}$ after treatment was assayed for leptin level using an EIA kit (Millipore Corporation, Billerica, MA, USA) following a protocol provided by the manufacturer. 


\section{Statistical analysis}

All data are reported as mean + S.E.M. of repeated experiments on the placental syncytiotrophoblasts prepared from different placentae. Paired Student's t-test or one-way ANOVA test followed by the Student-Newman-Keuls test was used where appropriate to assess significant differences. Significance was set at $P<0.05$.

\section{Declaration of interest}

The authors declare that there is no conflict of interest that could be perceived as prejudicing the impartiality of the research reported.

\section{Funding}

This work was supported by the National Natural Science Foundation of China (31071313), the National Key Basic Research Program of China (2011CB944403), and the Shanghai Committee of Science and Technology (O8JC1419800).

\section{References}

Ashworth CJ, Hoggard N, Thomas L, Mercer JG, Wallace JM \& Lea RG 2000 Placental leptin. Reviews of Reproduction 5 18-24. (doi:10.1530/ ror.0.0050018)

Bahl OP 1977 Human chorionic gonadotropin, its receptor and mechanism of action. Federation Proceedings 36 2119-2127.

Bhat NR, Zhang P \& Mohanty SB 2007 p38 MAP kinase regulation of oligodendrocyte differentiation with CREB as a potential target. Neurochemistry Research 32 293-302. (doi:10.1007/s11064-0069274-9)

Bi S, Gavrilova O, Gong DW, Mason MM \& Reitman M 1997 Identification of a placental enhancer for the human leptin gene. Journal of Biological Chemistry 272 30583-30588. (doi:10.1074/jbc.272.48.30583)

Chardonnens D, Cameo P, Aubert ML, Pralong FP, Islami D, Campana A, Gaillard RC \& Bischof P 1999 Modulation of human cytotrophoblastic leptin secretion by interleukin-1alpha and 17beta-oestradiol and its effect on HCG secretion. Molecular Human Reproduction 5 1077-1082. (doi:10.1093/molehr/5.11.1077)

Coya R, Gualillo O, Pineda J, Garcia MC, Busturia MA, Aniel-Quiroga A, Martul P \& Senaris RM 2001 Effect of cyclic $3^{\prime}, 5^{\prime}$-adenosine monophosphate, glucocorticoids, and insulin on leptin messenger RNA levels and leptin secretion in cultured human trophoblast. Biology of Reproduction 65 814-819. (doi:10.1095/biolreprod65.3.814)

Cronier L, Bastide B, Herve JC, Deleze J \& Malassine A 1994 Gap junctional communication during human trophoblast differentiation: influence of human chorionic gonadotropin. Endocrinology 135 402-408. (doi:10.1210/en.135.1.402)

Daoud G, Amyot M, Rassart E, Masse A, Simoneau L \& Lafond J 2005 ERK $1 / 2$ and $\mathrm{p} 38$ regulate trophoblasts differentiation in human term placenta. Journal of Physiology 566 409-423. (doi:10.1113/jphysiol. 2005.089326)

Ebihara K, Ogawa Y, Isse N, Mori K, Tamura N, Masuzaki H, Kohno K, Yura S, Hosoda K, Sagawa N et al. 1997 Identification of the human leptin 5'-flanking sequences involved in the trophoblast-specific transcription. Biochemical and Biophysical Research Communications 241 658-663. (doi:10.1006/bbrc.1997.7869)

Forhead AJ \& Fowden AL 2009 The hungry fetus? Role of leptin as a nutritional signal before birth Journal of Physiology 587 1145-1152. (doi:10.1113/jphysiol.2008.167072)

Gambino YP, Maymo JL, Perez-Perez A, Duenas JL, Sanchez-Margalet V, Calvo JC \& Varone CL 2010 17Beta-estradiol enhances leptin expression in human placental cells through genomic and nongenomic actions. Biology of Reproduction 83 42-51. (doi:10.1095/biolreprod.110. 083535)

Gettys TW, Harkness PJ \& Watson PM 1996 The beta 3-adrenergic receptor inhibits insulin-stimulated leptin secretion from isolated rat adipocytes. Endocrinology 137 4054-4057. (doi:10.1210/en.137.9.4054)

Henson MC \& Castracane VD 2006 Leptin in pregnancy: an update. Biology of Reproduction 74 218-229. (doi:10.1095/biolreprod.105. 045120)

Henson MC, Swan KF \& O'Neil JS 1998 Expression of placental leptin and leptin receptor transcripts in early pregnancy and at term. Obstetrics and Gynecology 92 1020-1028. (doi:10.1016/S0029-7844(98)00299-3)

Highman TJ, Friedman JE, Huston LP, Wong WW \& Catalano PM 1998 Longitudinal changes in maternal serum leptin concentrations, body composition, and resting metabolic rate in pregnancy. American Journal of Obstetrics and Gynecology 178 1010-1015. (doi:10.1016/ S0002-9378(98)70540-X)

Hytinantti T, Koistinen HA, Koivisto VA, Karonen SL, Rutanen EM \& Andersson S 2000a Increased leptin concentration in preterm infants of pre-eclamptic mothers. Archives of Disease in Childhood. Fetal and Neonatal Edition 83 F13-F16. (doi:10.1136/fn.83.1.F13)

Hytinantti TK, Koistinen HA, Teramo K, Karonen SL, Koivisto VA \& Andersson S $2000 \mathrm{~b}$ Increased fetal leptin in type I diabetes mellitus pregnancies complicated by chronic hypoxia. Diabetologia 43 709-713. (doi:10.1007/s001250051367)

Jansson N, Greenwood SL, Johansson BR, Powell TL \& Jansson T 2003 Leptin stimulates the activity of the system A amino acid transporter in human placental villous fragments. Journal of Clinical Endocrinology and Metabolism 88 1205-1211. (doi:10.1210/jc.2002-021332)

Kliman HJ, Nestler JE, Sermasi E, Sanger JM \& Strauss JF III 1986 Purification, characterization, and in vitro differentiation of cytotrophoblasts from human term placentae. Endocrinology 118 1567-1582. (doi:10.1210/endo-118-4-1567)

Kraiem Z, Sadeh O, Blithe DL \& Nisula BC 1994 Human chorionic gonadotropin stimulates thyroid hormone secretion, iodide uptake, organification, and adenosine $3^{\prime}, 5^{\prime}$-monophosphate formation in cultured human thyrocytes. Journal of Clinical Endocrinology and Metabolism 79 595-599. (doi:10.1210/jc.79.2.595)

Kurtzman JT, Wilson H \& Rao CV 2001 A proposed role for hCG in clinical obstetrics. Seminars in Reproductive Endocrinology 19 63-68. (doi:10. 1055/s-2001-13912)

Lage M, Garcia-Mayor RV, Tome MA, Cordido F, Valle-Inclan F, Considine RV, Caro JF, Dieguez C \& Casanueva FF 1999 Serum leptin levels in women throughout pregnancy and the postpartum period and in women suffering spontaneous abortion. Clinical Endocrinology $\mathbf{5 0}$ 211-216. (doi:10.1046/j.1365-2265.1999.00637.x)

Magarinos MP, Sanchez-Margalet V, Kotler M, Calvo JC \& Varone CL 2007 Leptin promotes cell proliferation and survival of trophoblastic cells. Biology of Reproduction 76 203-210. (doi:10.1095/biolreprod.106. 051391)

Margetic S, Gazzola C, Pegg GG \& Hill RA 2002 Leptin: a review of its peripheral actions and interactions. International Journal of Obesity and Related Metabolic Disorders 26 1407-1433. (doi:10.1038/sj.ijo. 0802142)

Marinoni E, Letizia C, Ciardo F, Corona G, Moscarini M \& Di lorio R 2008 Effects of prenatal betamethasone administration on leptin and adiponectin concentrations in maternal and fetal circulation. American Journal of Obstetrics and Gynecology 141 e141-e146. (doi:10.1016/ j.ajog.2008.02.047)

Masuzaki H, Ogawa Y, Sagawa N, Hosoda K, Matsumoto T, Mise H, Nishimura H, Yoshimasa Y, Tanaka I, Mori T et al. 1997 Nonadipose tissue production of leptin: leptin as a novel placenta-derived hormone in humans. Nature Medicine 3 1029-1033. (doi:10.1038/nm0997-1029)

Maymo JL, Perez Perez A, Sanchez-Margalet V, Duenas JL, Calvo JC \& Varone CL 2009 Up-regulation of placental leptin by human chorionic gonadotropin. Endocrinology 150 304-313. (doi:10.1210/en.20080522)

Maymo JL, Perez Perez A, Duenas JL, Calvo JC, Sanchez-Margalet V \& Varone CL 2010 Regulation of placental leptin expression by cyclic adenosine $5^{\prime}$-monophosphate involves cross talk between protein kinase $\mathrm{A}$ and mitogen-activated protein kinase signaling pathways. Endocrinology 151 3738-3751. (doi:10.1210/en.2010-0064) 
Meng XL, Rennert OM \& Chan WY 2007 Human chorionic gonadotropin induces neuronal differentiation of PC12 cells through activation of stably expressed lutropin/choriogonadotropin receptor. Endocrinology 148 5865-5873. (doi:10.1210/en.2007-0941)

Ni XT, Duan T, Yang Z, Guo CM, Li JN \& Sun K 2009 Role of human chorionic gonadotropin in maintaining 11 beta-hydroxysteroid dehydrogenase type 2 expression in human placental syncytiotrophoblasts. Placenta 30 1023-1028. (doi:10.1016/j.placenta.2009.10.005)

Nuamah MA, Yura S, Sagawa N, Itoh H, Mise H, Korita D, Kakui K, Takemura M, Ogawa Y, Nakao K et al. 2004 Significant increase in maternal plasma leptin concentration in induced delivery: a possible contribution of pro-inflammatory cytokines to placental leptin secretion. Endocrine Journal 51 177-187. (doi:10.1507/endocrj.51.177)

Rey A, Manen D, Rizzoli R, Ferrari SL \& Caverzasio J 2007 Evidences for a role of p38 MAP kinase in the stimulation of alkaline phosphatase and matrix mineralization induced by parathyroid hormone in osteoblastic cells. Bone 41 59-67. (doi:10.1016/j.bone.2007.02.031)

Roux PP \& Blenis J 2004 ERK and p38 MAPK-activated protein kinases: a family of protein kinases with diverse biological functions. Microbiology and Molecular Biology Reviews 68 320-344. (doi:10.1128/MMBR.68.2. 320-344.2004)

Sengupta N, Vinod PK \& Venkatesh KV 2007 Crosstalk between cAMP-PKA and MAP kinase pathways is a key regulatory design necessary to regulate FLO11 expression. Biophysical Chemistry 125 59-71. (doi:10. 1016/j.bpc.2006.06.012)
Shi QJ, Lei ZM, Rao CV \& Lin J 1993 Novel role of human chorionic gonadotropin in differentiation of human cytotrophoblasts. Endocrinology 132 1387-1395. (doi:10.1210/en.132.3.1387)

Strauss JF III, Kido S, Sayegh R, Sakuragi N \& Gafvels ME 1992 The cAMP signalling system and human trophoblast function. Placenta $\mathbf{1 3}$ 389-403. (doi:10.1016/0143-4004(92)90047-W)

Sun K, Yang K \& Challis JR 1997 Differential regulation of 11 betahydroxysteroid dehydrogenase type 1 and 2 by nitric oxide in cultured human placental trophoblast and chorionic cell preparation. Endocrinology 138 4912-4920. (doi:10.1210/en.138.11.4912)

Szkudelski T, Nowicka E \& Szkudelska K 2005 Leptin secretion and protein kinase A activity. Physiological Research 54 79-85.

Trujillo ME, Lee MJ, Sullivan S, Feng J, Schneider SH, Greenberg AS \& Fried SK 2006 Tumor necrosis factor alpha and glucocorticoid synergistically increase leptin production in human adipose tissue: role for p38 mitogen-activated protein kinase. Journal of Clinical Endocrinology and Metabolism 91 1484-1490. (doi:10.1210/jc.2005-1901)

Yang M, Lei ZM \& Rao ChV 2003 The central role of human chorionic gonadotropin in the formation of human placental syncytium. Endocrinology 144 1108-1120. (doi:10.1210/en.2002-220922)

Received 22 February 2011

First decision 24 February 2011

Accepted 11 May 2011 